\title{
Analysis for Activation of Old Shopping Streetsbased on the Surveys of Citizens and Storekeepers
}

\author{
Gao Wa ${ }^{1}$, Yoichi Seki ${ }^{1}$, Kenji Amagai $^{1} \&$ Takayuki Takarada ${ }^{1}$ \\ ${ }^{1}$ Gunma University Faculty of Science and Technology, Kiryu, Gunma, Japan \\ Correspondence: Yoichi Seki, Division of Electronics and Informatics, Gunma University Faculty of Science and \\ Technology, Tenjin-cho 1-5-1, Kiryu, Gunma, Japan. Tel: 81-277-301-806. E-mail: seki@cs.gunma-u.ac.jp
}

\author{
Received: November 27, 2013 Accepted: January 7, 2014 Online Published: March 24, 2014 \\ doi:10.5539/ijms.v6n2p92 URL: http://dx.doi.org/10.5539/ijms.v6n2p92
}

\begin{abstract}
In order to activate the old shopping street in Kiryu city, we build two hypotheses about the cause that few people visit the street. First, comparing with shopping malls, moving among the shops is necessary in old shopping street, this inconvenience prevent the visiting. Second, many citizens do not understood the charm of the old shopping street well. To verify these hypotheses, we conduct two questionnaire surveys of citizens of Kiryu city as consumers and the owners of shops in old shopping street. Based on these results, we clarify the current state of the old shopping streets, and proposeremedial measures to contribute to activate the old shopping street of Kiryu City.
\end{abstract}

Keywords: purchasing behavior, AIDA, questionnairesurvey, EV bus

\section{Introduction}

These days, the old shopping streets downtown in most provincial cities in Japan have lost their bustle, and these circumstances have greatly impaired the regional economy. This is true of Kiryu City in Gunma prefecture, whose shopping streets downtown are an emblem of the city. In order to activate the old shopping streets, we are trying to get to know the current state of it and find effective methods to deal with the problems. In details, we conduct two big scale questionnaire surveys of citizens of Kiryu city as consumers and the owners of shops in old shopping street as sellers to verify the two following hypotheses, which are problems need to deal with of the old shopping street.

1) Comparing with shopping malls, moving among the shops is necessary in old shopping street. This inconvenience prevents the visiting.

2) The charm of the old shopping street is not known well.

Then, we propose the remedial measures to contribute to activate the old shopping street of Kiryu City.

\subsection{Related Research}

\subsubsection{Research about the Visitors of Specific Shopping Destination}

Factors, such as increasing spending capacity of consumers, growing car ownership, combined with modern shopping habits as buying in large amounts, made the customers changed their shopping place.

Cees etc. (2003) conducted a survey questionnaire on 150 visitors and buyers to a mall to identify the motives of them for large-scale shopping malls. Further analysis was done based on 130 suitable returned forms and it was found that about half of them visited the shopping mall for pleasure. Also about half of them responded that they would have bought their goods in the central city had the peripheral mall not existed. Moreover, the shopping mall is more attractive for consumers living a longer distance from the mall.

Cilin etc. (2003) investigated the shopping linkages between a closely integrated new shopping precinct, incorporating an edge-of-centre superstore, in the small town centre of Llanelli in South Wales. The questionnaire survey was taken at seven places in the centre during the trading peak hours and 642 copies about the respondent's specific information and the distance to the stores were obtained. Whether going to go other six places was asked and the customers' movement was paid attention to. It is evident that the principal shopping attractions 'anchor' the nodes of shopping activity and largely determine the major patterns of pedestrian flows throughout a centre. 


\subsubsection{Research about the Impact on Shopping Behavior}

Adam etc. (1996) investigate the impact that specific anchor stores and other physical characteristics of shopping centers have on the image consumers' possess for shopping centers, and through image, on indicators of shopping center patronage, such as the aggregate consideration and the share of choice. In addition, center characteristics that determine the image of the shopping centers in their market is identified for it is more important from a manager's perspective.

Ruby (1999) examined the impact of going shopping among married households. Key constructs are sex and shopping context which determine shopping responsibility among household members. Based on a large scale survey that included statistically viable numbers of male as well as female respondents and find a great deal of consensus regarding shopping responsibility among the sampled households. Although men are playing a significant role in shopping activities, particularly shopping for household groceries, shopping remains a gendered activity but it is not a pleasureless activity. At last, the supermarket is likely to be the retail setting where the changing roles will make the greatest impact is concluded.

\subsection{Comparison of the Conventional Researches and This Study}

Cees investigated the visitors of a large-scale mall only and evaluated the absorption of the shop and the distance,but the quantity and the character of the target are restricted. Colin paid attention on the relation among the shops and examined the visitors" shopping pattern, but the object was restricted to the visitors in the fixed time zone. Both the objects are in their shopping time so the accuracy of theanswer is doubted for the time convenience. Also, since both investigationswere in the limited time, the representation of the visitors would be under the influence of the weather or the events, etc. on the day. In addition, Adam investigate the impact that specific anchor stores but it is limited to one kind of store.Ruby examined the motivation of going shopping. However, it only focus on the difference of sex and shopping context.On the other hand,in order to understand purchasing behavior of citizens, weconducted large-scale investigation to the whole resident of Kiryu city, and since the investigation period is not one day but one month, thedata reflects a usual shopping situation was obtained. Next, there are questions not only about buyer activity but also about the evaluation point to various kinds of shops. That is to say, not only the action step, the last step of AIDA (Attention, Interest, Desire, Action, Lewis (1985)), but also other steps, which show the reason of the action, can also been grasped. Then, since this questionnaire survey was answered in the time of a respondent's sufficient convenience, the data from many viewpointswere obtained. Lastly, Since questionnaire survey for both the owner ofshops in old shopping street andcitizens of Kiryu city were conducted,comparison from many viewpoints can be done and the present condition of old shopping street has been grasped more correctly.

\section{Method}

In this study, we conducted two big-scale-questionnaire surveys of citizens of Kiryu city as consumers and the owners of shops in old shopping street. We analyzed the data, using R:a free software programming language and software environment for statistical computing and graphics, for example, Spector (2008), and evaluate the Shops in old shopping street, Supermarket and Mall from viewpoint of goods, traffic, and pleasure and so on, and comparingthe thought on old shopping street by both the citizens and the owners. Based on those results, we verified two hypotheses about the problems of the old shopping street and proposed the remedy for the problems.

\subsection{The Definition Used in This Study}

Kiryu city, where the questionnaire surveysconducted, is a local city in Gunma prefecture, and is located about $100 \mathrm{~km}$ north of Tokyo. Once be famous of high-quality fabrics as well as Kyoto city. It comes in being as Old Yamada Gun at the time of 1921. The present city regionis based on old Yamada Gun, and consists of several mergers. In this paper, we divided Kiryu city into four areas by geographical location, represented as Old Town, New town, Across river and Detached area as shown in Figure 1. 


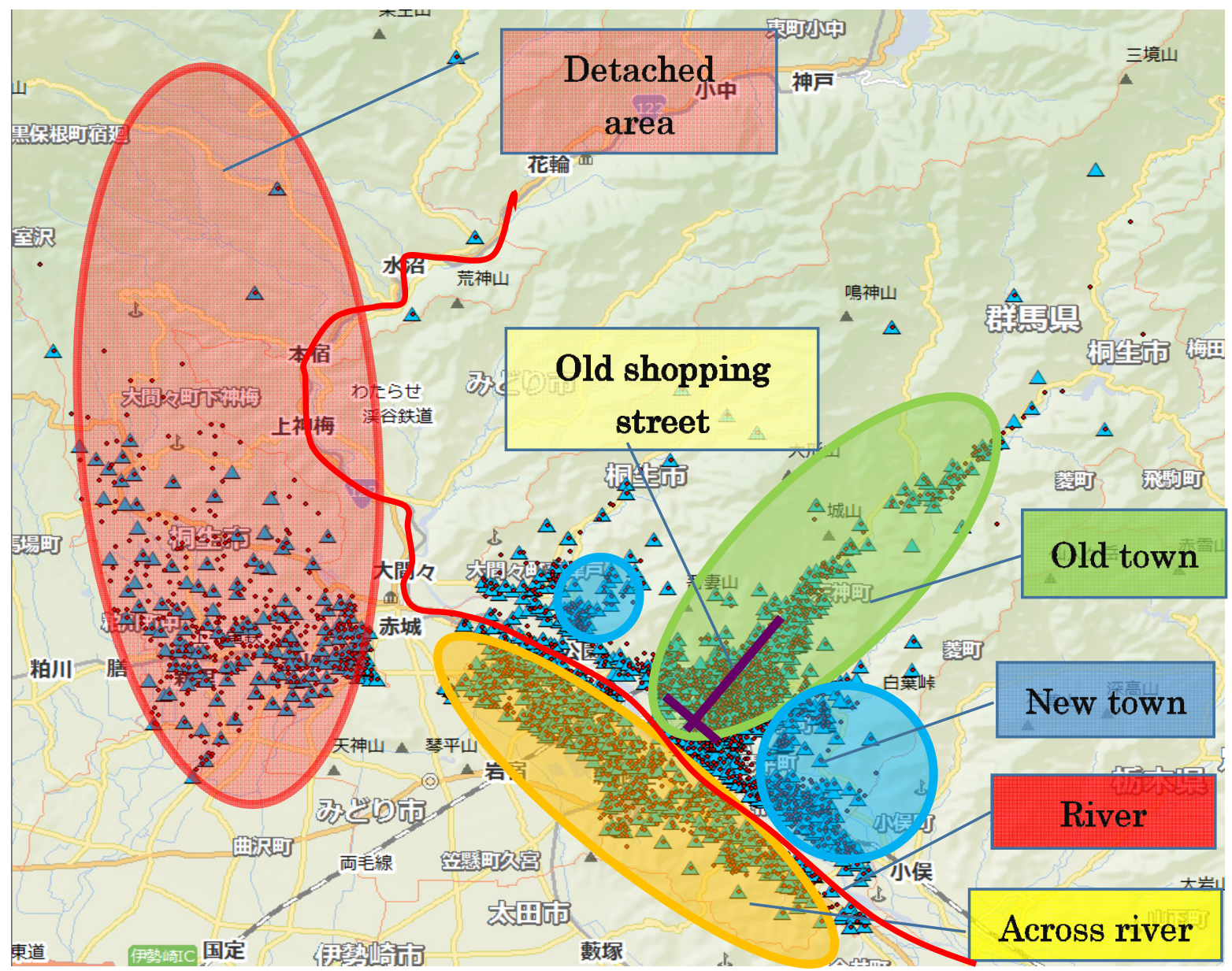

Figure 1. Area divided in Kiryu city

There are 63,576 females and 59,217 male, total 122,793 people living in Kiryu city. In this paper, the young, Middle age and the old means the people aged 0 to 39, 40 to 59, 60 or more, respectively.

Moreover, the store in Kiryu city is classified into following three types. First, the shops located in the Old town, which serves as a problem and a candidate to be improved, and being the target of owners'survey, named as "Shops in old shopping street". Second, 41 representative large-scale retailer stores been selected located in Kiryu city named as "Supermarket". Finally, the five large-scaled shopping malls, which located in a suburb near Kiryu city, named as "Mall".

\subsection{The Summary of Questionnaire Surveys}

\subsubsection{Questionnaire Survey of Owners of Shops in Old Shopping Street}

One questionnaire surveywe conducted is on the owners of the Shops in old shopping street of Kiryu city from February 16 to 28, 2009 to get to known the financial condition of every shop and the owners' recognition to present condition, etc. With the cooperation of Kiryu Chamber of Commerce \&Industry and a trade association of shops, 504 papersof the questionnaire was distributed and 208 have been collected. A part of the data is used in this paper.

\subsubsection{Questionnaire Survey of Citizens of Kiryu City}

Another big-scale-questionnaire surveys we conducted is on the citizens of Kiryu city in November 2012 to get to known the shopping activity of them. This questionnaire were sent to 10,000 householders whom are random sampled from a total 49,411 householders of Kiryu and returned 2,963 ones; it means about $6 \%$ of the total or the $29.63 \%$ of the sample. The survey's content is as follows: 
Q1: The name of the stations of bus or train to be used (will not been discussed in this paper)

Q2: The personality of the answer, such as the sex, age, address, traffic means (bicycle, car, train, on foot, etc.) and whether ownlicense.

Q3: Where and how many times to do the shopping during one month, activities done in the store, such as foods, clothes, daily goods, window-shopping, etc. and the traffic means used.

Q4: The points to choose or not to choose the store.

Q5 to Q7: Others about our project (will not been discussed in this paper).

\section{Results}

\subsection{The Results of Questionnaire Surveys of Owners of Shops in Old Shopping Street}

There are many questions in this questionnaire survey but only those related to the problems to deal with will be mentioned in this paper.

\subsubsection{Summary of the Shops Condition}

There are 94 (45\%) private-manage-shop, 110 (53\%) corporate-manage-shop and 4 (2\%) unknown shops in the total 208 shops that responded to the questionnaire survey. Moreover, about half of them use a part of home as the shop and all the employees are families.

For the business years, as shown in Table 1, more than half of them are 50 years or more.

Table 1. Business years of shops in old shopping street

\begin{tabular}{llllllllll}
\hline Years $(\mathrm{Y})$ & Unknown & $\mathrm{Y}<3$ & $3 \leq \mathrm{Y}<5$ & $5 \leq \mathrm{Y}<10$ & $10 \leq \mathrm{Y}<20$ & $20 \leq \mathrm{Y}<30$ & $30 \leq \mathrm{Y}<40$ & $40 \leq \mathrm{Y}<50$ & $\mathrm{Y} \geqq 50$ \\
\hline frequency & 4 & 6 & 8 & 8 & 18 & 27 & 19 & 17 & 101 \\
$\%$ & $1.9 \%$ & $2.9 \%$ & $3.8 \%$ & $3.8 \%$ & $8.7 \%$ & $13.0 \%$ & $9.1 \%$ & $8.2 \%$ & $48.6 \%$ \\
\hline
\end{tabular}

\subsubsection{The Financial Condition of the Shops}

First, in order to investigate business conditions of the shops, we set a question about the number of purchase customers per day for the last week at the investigation time. As shown in Table 2, about $40 \%$ shops had less than 20 customers.

Table 2. Number of purchase customers per day for the last week

\begin{tabular}{|c|c|c|c|c|c|c|c|}
\hline $\begin{array}{l}\text { number } \\
\text { customers (C) }\end{array}$ & Unknown & $\mathrm{C}<20$ & $20 \leq \mathrm{C}<40$ & $40 \leq C<60$ & $60 \leq C<80$ & $80 \leq \mathrm{C}<100$ & $\mathrm{C} \geqq 100$ \\
\hline frequency(shops) & 46 & 80 & 38 & 15 & 7 & 3 & 19 \\
\hline$\%$ & $22.1 \%$ & $38.5 \%$ & $18.3 \%$ & $7.2 \%$ & $3.4 \%$ & $1.4 \%$ & $9.1 \%$ \\
\hline
\end{tabular}

About income, number of customers and profit, as shown in Table 3, compare with 3 years ago, less than 10\% shops grow and more than $70 \%$ shops reduced. That is to say, the business condition is becoming worse.

Table 3. Compare with 3 years ago

\begin{tabular}{lllllll}
\hline & $\begin{array}{l}\text { Growth by or } \\
\text { more than } 10 \%\end{array}$ & $\begin{array}{l}\text { Growth less than } \\
10 \%\end{array}$ & No Change & $\begin{array}{l}\text { Reduce less than } \\
10 \%\end{array}$ & $\begin{array}{l}\text { Reduce by or more } \\
\text { than } 10 \%\end{array}$ & Unknown \\
\hline Income & 10 & 8 & 24 & 38 & 119 & 9 \\
& $5 \%$ & $4 \%$ & $12 \%$ & $18 \%$ & $57 \%$ & $4 \%$ \\
Number of customers & 9 & 9 & 32 & 45 & 100 & 13 \\
& $4 \%$ & $4 \%$ & $15 \%$ & $22 \%$ & $48 \%$ & $6 \%$ \\
Profits & 5 & 10 & 28 & 39 & 114 & 12 \\
& $2 \%$ & $5 \%$ & $13 \%$ & $19 \%$ & $55 \%$ & $6 \%$ \\
\hline
\end{tabular}




\subsubsection{Statistics about the Problems of the Old Shopping Street}

About the problem of old shopping street, we list up all the problems conceivable in the questionnaire and ask the owner to multiple select all the problems they thought. As shown in Figure 2, many problems, such as too many empty shops, no suction institution, no parking, etc. exist.

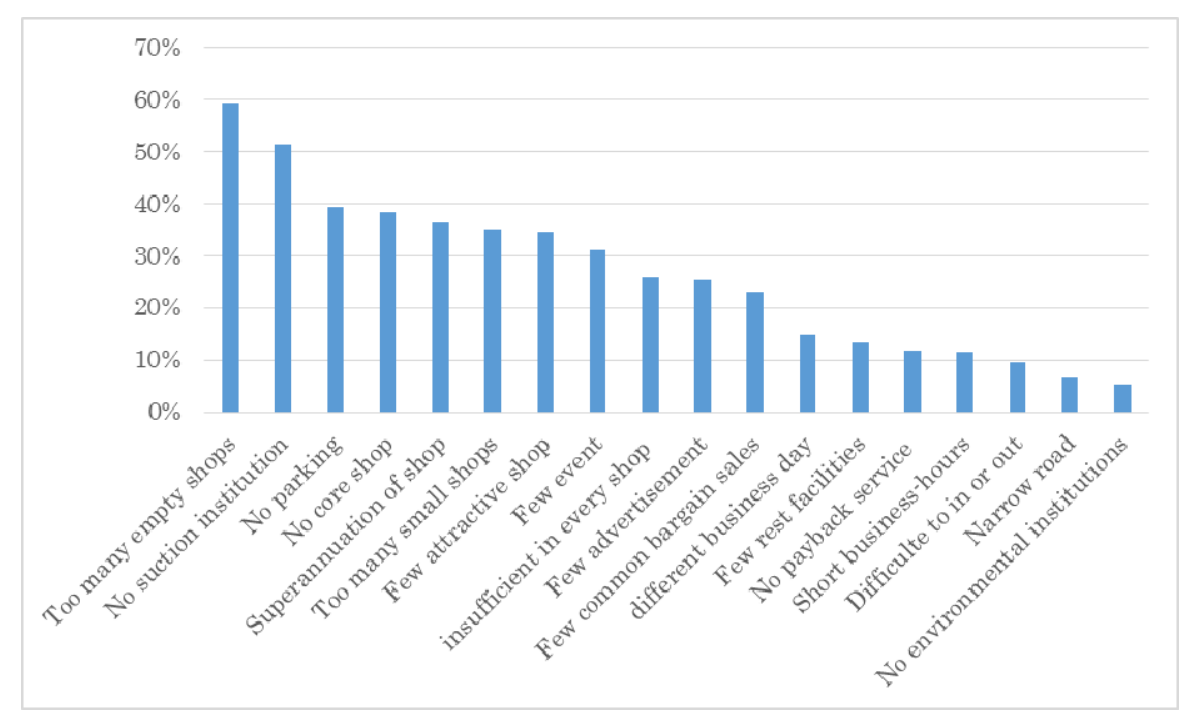

Figure 2. Problems selected by the shop owners

\subsection{The Results of Questionnaire Surveys of Citizens of Kiryu City}

There are 7 questions in this questionnaire survey. Questions 2 to 4 will be discussed here for the relation to the problems to deal with. Other questions were analyzed by Seki (2012).

\subsubsection{The Statistics on the Characteristics of Respondents}

Question 2 related to age, gender, licensing presence of their families and the respondents themselves and the result is shown below. As shown in Table 4, 1,665 male and 1,043 female answered the questionnaire survey.There is the possibility that the wife answered using the name of the householder, so the analysis according to sex will not be conducted in this study.

Table 4. Age, sex, licensing presence of the respondent

\begin{tabular}{|c|c|c|c|c|c|c|c|c|c|c|c|}
\hline & & \multicolumn{3}{|c|}{ The young } & \multicolumn{2}{|c|}{ Middle-age } & \multicolumn{3}{|l|}{ The old } & \multirow{2}{*}{$\begin{array}{l}\text { Un- } \\
\text { known }\end{array}$} & \multirow[t]{2}{*}{ Total } \\
\hline & & Teens & Twenties & Thirties & Forties & Fifties & Sixties & Seventies & Eighties & & \\
\hline \multirow[t]{3}{*}{ Sex } & Male & 3 & 17 & 119 & 220 & 375 & 524 & 376 & 8 & 23 & 1665 \\
\hline & Female & 6 & 23 & 76 & 211 & 237 & 305 & 172 & 3 & 10 & 1043 \\
\hline & Unknown & 0 & 2 & 6 & 5 & 8 & 15 & 19 & 0 & 201 & 256 \\
\hline Car & own & 3 & 36 & 196 & 421 & 597 & 767 & 428 & 8 & 38 & 2494 \\
\hline \multirow[t]{3}{*}{ License } & Not own & 6 & 6 & 4 & 7 & 13 & 52 & 111 & 3 & 3 & 205 \\
\hline & Unknown & 0 & 0 & 2 & 8 & 10 & 27 & 25 & 0 & 193 & 265 \\
\hline & $\%$ & $33.3 \%$ & $85.7 \%$ & $97.0 \%$ & $96.6 \%$ & $96.3 \%$ & $90.7 \%$ & $75.9 \%$ & $72.7 \%$ & $16.2 \%$ & $84.1 \%$ \\
\hline Total & & 9 & 42 & 202 & 436 & 620 & 846 & 564 & 11 & 234 & 2964 \\
\hline
\end{tabular}

About the age, it is 1,421 the old, 1,056 middle aged and 253 the young. Most persons own license regardless of sex and age, especially for the middle age. There are less young persons in Kiryu city and the questionnaire surveyis conducted every householderunit, so less young person in respondent is reasonable.

As shown in Table 5, 993 persons living in Across river, 841 persons living in Old Town, 676 persons living in New Town and 453 persons living in Detached area answered the questionnaire survey. 
Table 5. Living area of the respondent

\begin{tabular}{llllll}
\hline & Old town & New town & Across river & Detached area & Total \\
\hline Answers & 841 & 676 & 993 & 453 & 2963 \\
$\%$ & $28.4 \%$ & $22.8 \%$ & $33.5 \%$ & $15.3 \%$ & $100.0 \%$ \\
\hline
\end{tabular}

About $6 \%$ family answered thequestionnaire survey and there is no clear deviation in age or region as mentioned above, so it is thought that Kiryu citizens' general shopping situation can be grasped almost correctly with this survey data.

\subsubsection{Statistics about Shopping Activity}

In this survey, we asked about shopping to the main person who usually goes to shopping in his/her home. Question 3 is the main part of the question in which about where respondents were shopping during the month before the questionnaire survey.At the first, rrespondents were asked to write the frequency of shopping in every individual shop, next, to check all propose to visit the shop.In the answer sheet, we illustrate vertically stores' name of shops, and illustrate horizontally shopping activities done in the store, such as foods, clothes, daily goods, window-shopping, etc. Respondentscheck the corresponding cells. It is difficult to ask all of the stores located in Kiryu city, so we limited alternatives in the questionnaire to the representative shopping placesin Kiryu city, and they classified in three kinds: Shops in Old shopping street, Supermarket and Mall. In addition, means to go to the shopping, such as bicycle, car, walk were investigated for each shop. Number of total times of visiting every shop is shown separately by visiting purpose in Figure 3 as a bar graph. The horizontal axis of bar graph shows propose and total times of all respondent who visiting that shop. The vertical axis of bar graph shows the ratio of visiting an individual shop to all shops. As shown in Figure 3, for propose of visiting shops, food and daily commodities are obviously greater in number for Supermarket. Differentto Supermarket, Shops in old shopping street are used for multiple purposes.

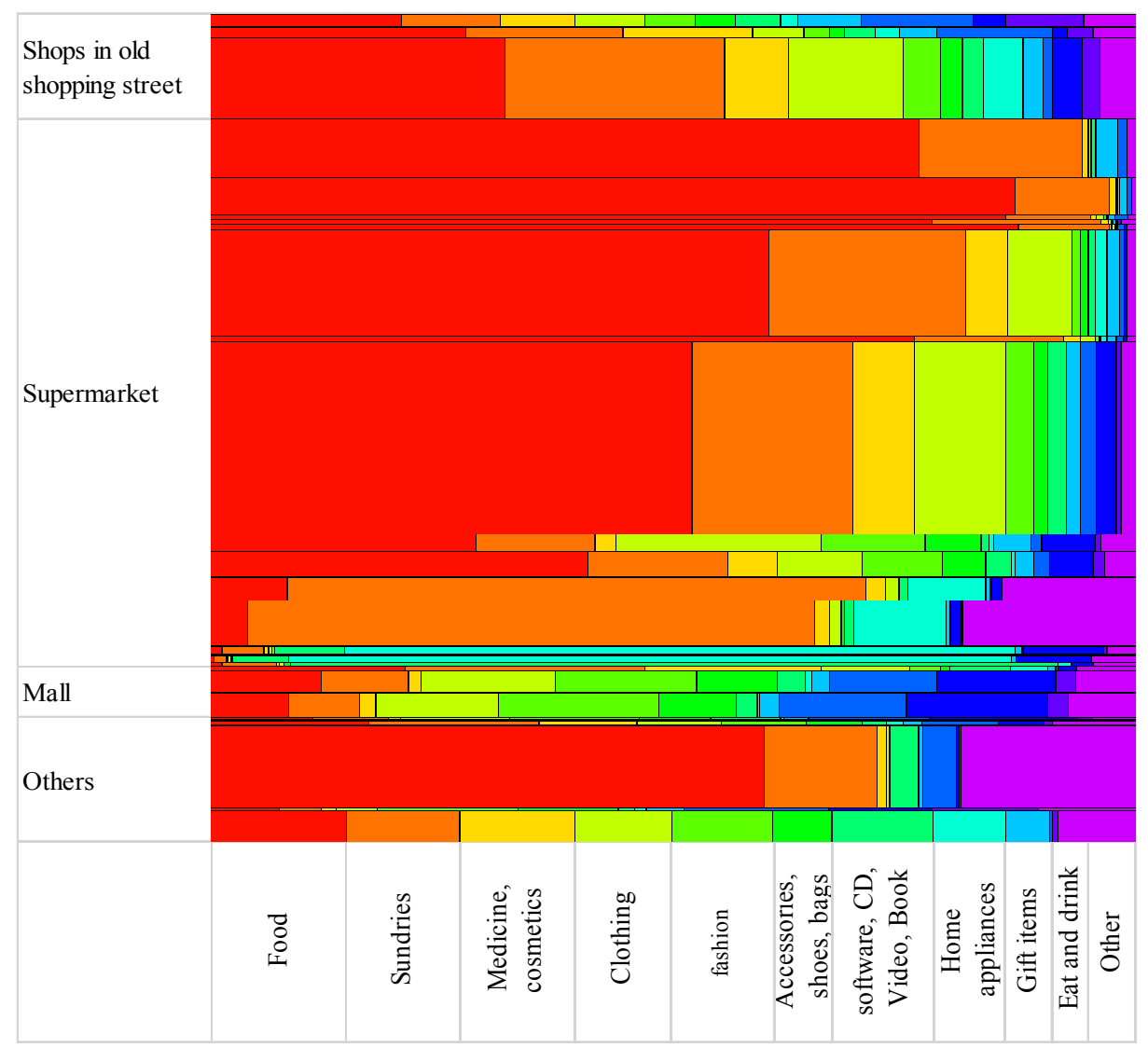

Figure 3. Number of total times of visiting every shop by visiting purpose 
For visiting means, as shown in Table 6 , private cars were used basically. More specifically, 2/3 visitors used private carsand of about $1 / 3$ used bicycle or on foot for Shops in old shopping street, nearly $90 \%$ visitors used private cars for Supermarket and almost all of the visitors used private cars for Mall.

Table 6. Visiting means to stores

\begin{tabular}{llllllll}
\hline & On foot & Bicycle & Auto-bicycle & Car & Bus & Train & Total \\
\hline Shops in old & 982 & 1067 & 106 & 4673 & 124 & 88 & 7040 \\
shopping street & $13.9 \%$ & $15.2 \%$ & $1.5 \%$ & $66.4 \%$ & $1.8 \%$ & $1.3 \%$ & $100.0 \%$ \\
Supermarket & 2400 & 2325 & 650 & 36395 & 82 & 14 & 41866 \\
& $5.7 \%$ & $5.6 \%$ & $1.6 \%$ & $86.9 \%$ & $0.2 \%$ & $0.0 \%$ & $100.0 \%$ \\
Mall & 4 & 27 & 2 & 3058 & 4 & 16 & 3111 \\
& $0.1 \%$ & $0.9 \%$ & $0.1 \%$ & $98.3 \%$ & $0.1 \%$ & $0.5 \%$ & $100.0 \%$ \\
\hline
\end{tabular}

Figure 4 shown visiting rate between shopping places separated by the four areas. It can be seen that for Supermarket, Mall and others, there are little difference among the four areas. However, for Shops in shopping street, usage is very different and decreased in the order of Old town, New town, Across river and Detached area.

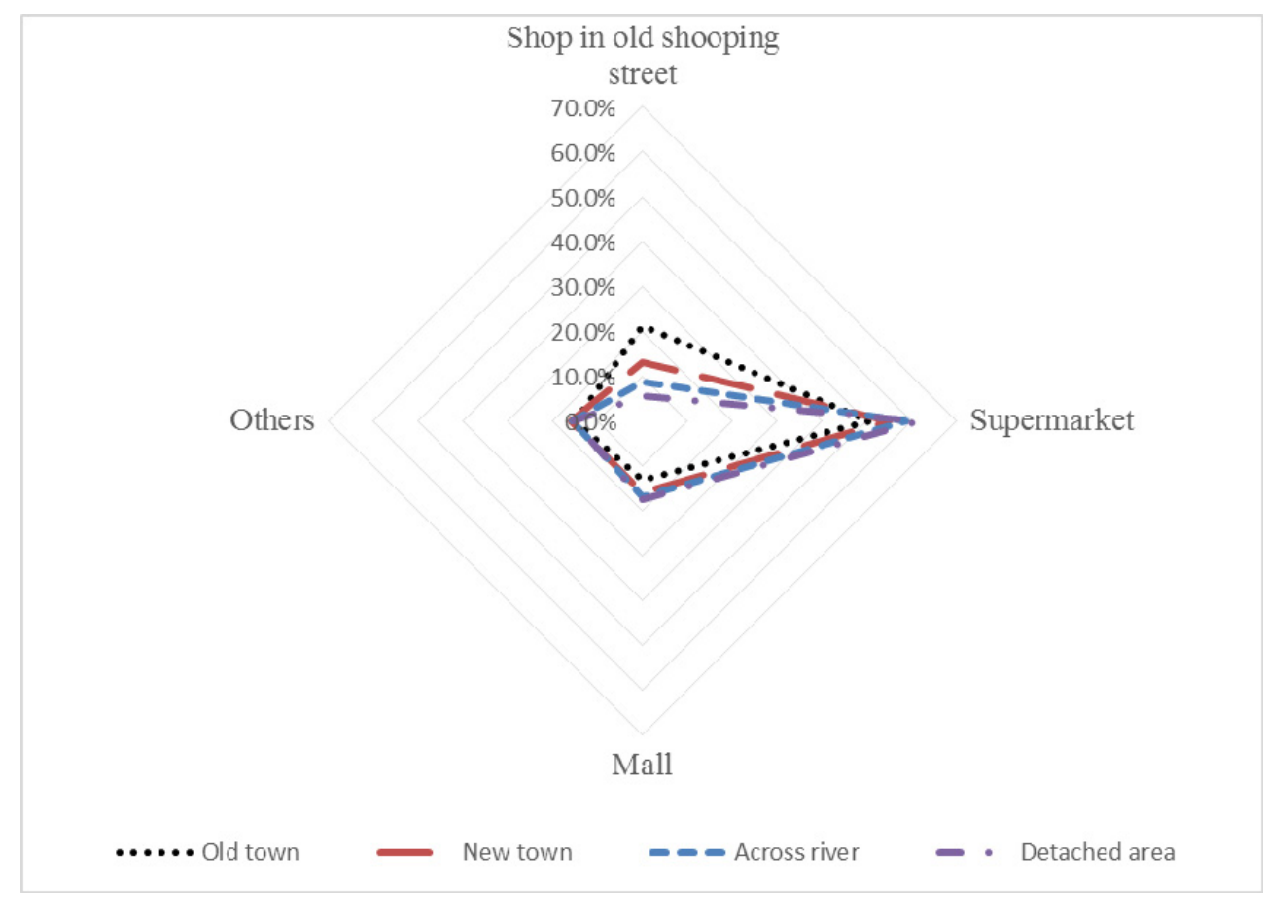

Figure 4. Visiting rate between Shopping places by different areas

\subsubsection{Statistics about Shop Evaluation}

In Question 4, respondent was asked to write $\circ$ or $\times$ for the three types of stores, which are Shops in old shoppingstreet, Supermarket and Mall, about 25 points shown in Table 4 . The $\circ$ means that the point is a good point makes the respondent choose the shop and the $\times$ means the point is a bad point makes the respondent do not choose the shop.

First, total number of both oand $\times$ was counted and calculated as point rate to find which point is considered for decide the shopping place. As shown in Table 7, "variety of goods", "parking" and "all can bought in one place" are the most important points for decision. "Cheap", "easy to find goods", "near", "having place for rest and meal" and "Goodatmosphere" are the points followed.

Then, average number of points in each evaluate object [(the number of $\circ$ ) - (the number of $\times$ )] for those three stores are shown at the rightside of Table 7. Average number of points in"parking","all can bought in one place" 
and "variety of goods" for Shops in old shopping street are low. "Cheap", "long business-hour", "having place for children", "having place for rest and meal" and"attractive advertising" are low also. On the other hand, "parking", "cheap", "variety of goods" and "all can be bought in one place" of Supermarket are high. It is similar of Mall to Supermarket and "Having favorite goods", "good atmosphere", "having place for rest and meal" are also evaluated highly but "Near" and "intimacy" are not good.

Table 7. Point rate and Average number of points of all that selected by respondent

\begin{tabular}{|c|c|c|c|c|c|}
\hline \multicolumn{2}{|c|}{ Evaluateobjects } & \multirow{3}{*}{$\begin{array}{l}\text { Point rate } \\
0.350\end{array}$} & \multicolumn{3}{|l|}{ Average number of points } \\
\hline & & & \multirow{2}{*}{$\begin{array}{l}\text { shops in Old Shopping Street } \\
-0.181\end{array}$} & \multirow{2}{*}{$\begin{array}{l}\text { Super-market } \\
0.384\end{array}$} & \multirow{2}{*}{$\frac{\text { Mall }}{0.389}$} \\
\hline Goods & Variety of goods & & & & \\
\hline & Easy to find goods & 0.217 & -0.006 & 0.096 & 0.114 \\
\hline & All can be bought in one place & 0.338 & -0.203 & 0.347 & 0.380 \\
\hline & Having favorite goods & 0.202 & -0.040 & 0.039 & 0.257 \\
\hline & Fresh and good sense & 0.177 & -0.016 & 0.077 & 0.167 \\
\hline & Cheap & 0.258 & -0.109 & 0.462 & 0.063 \\
\hline \multirow[t]{9}{*}{ Shop } & Good atmosphere & 0.212 & -0.024 & 0.057 & 0.332 \\
\hline & Intimacy & 0.113 & 0.098 & 0.014 & -0.040 \\
\hline & Famous & 0.108 & -0.010 & 0.039 & 0.092 \\
\hline & Individuality & 0.101 & 0.038 & 0.001 & 0.036 \\
\hline & Good service attitude & 0.118 & 0.028 & 0.045 & 0.080 \\
\hline & Product knowledge of clerk & 0.089 & 0.023 & 0.004 & 0.036 \\
\hline & After-sales service & 0.079 & 0.023 & 0.001 & 0.001 \\
\hline & Delivery & 0.068 & -0.013 & 0.001 & -0.010 \\
\hline & Long-opening Hours & 0.185 & -0.088 & 0.239 & 0.151 \\
\hline \multirow[t]{3}{*}{ Traffic } & Near & 0.218 & 0.050 & 0.323 & -0.077 \\
\hline & Parking & 0.352 & -0.218 & 0.407 & 0.317 \\
\hline & Convenient of bus & 0.080 & -0.030 & -0.012 & -0.036 \\
\hline \multirow[t]{4}{*}{ Pleasure } & Having place for children & 0.107 & -0.076 & 0.014 & 0.125 \\
\hline & Convenient of public facility & 0.070 & -0.025 & -0.004 & -0.011 \\
\hline & Convenient of ATM & 0.130 & -0.019 & 0.106 & 0.104 \\
\hline & Having place for rest and meal & 0.214 & -0.059 & 0.061 & 0.380 \\
\hline \multirow[t]{3}{*}{ Adv. } & Attractive advertising & 0.130 & -0.055 & 0.132 & 0.086 \\
\hline & Attractive event & 0.086 & -0.033 & -0.007 & 0.069 \\
\hline & Payback & 0.106 & -0.029 & 0.063 & -0.010 \\
\hline
\end{tabular}

In addition, regional differences of the evaluation are shown in Table 8. Distance to storeis regard importantly by the respondents living in New town and Old town but reverse by those living in Across river and Detached area. The reason of it can be thought as the difference in means of transportation. In addition, "long-business-hour" is not regarded so important by those living in detached area. Those living in all the area except old town regard pleasure important.

As shown in table 8. it can be seen that the Shops in old shopping street is evaluated highly by those living in old town but reverse by those living in detached area. In addition, Mall is evaluated highly by those living in across river but reverse by those living in old town. 
Table 8 . Average number of points separated by different area

\begin{tabular}{|c|c|c|c|c|c|c|c|c|c|c|c|c|c|c|c|c|}
\hline \multirow{2}{*}{\multicolumn{2}{|c|}{$\begin{array}{l}\text { Living area } \\
\text { Evaluate objects }\end{array}$}} & \multicolumn{4}{|c|}{ Old town } & \multicolumn{4}{|c|}{ New town } & \multicolumn{4}{|c|}{ Across river } & \multicolumn{3}{|c|}{ Detached area } \\
\hline & & PR & $\mathrm{O} 1$ & $\mathrm{O} 2$ & $\mathrm{O} 3$ & PR & $\mathrm{O} 1$ & $\mathrm{O} 2$ & $\mathrm{O} 3$ & PR & $\mathrm{O} 1$ & $\mathrm{O} 2$ & $\mathrm{O} 3$ & PR & $\mathrm{O} 2$ & $\mathrm{O} 3$ \\
\hline \multirow[t]{6}{*}{ Goods } & Variety of goods & 0.002 & 0.016 & 60.076 & -0.050 & 0.014 & $-0.026 C$ & 0.023 & -0.012 & 20.015 & -0.021 & -0.035 & 0.046 & -0.019 & $9-0.022-0.031$ & -0.029 \\
\hline & Easy to find goods & -0.003 & 0.059 & $9-0.036$ & -0.033 & 0.009 & 0.008 & -0.001 & $1-0.008$ & 80.009 & -0.023 & 0.002 & 0.021 & 0.000 & -0.0460 .060 & 0.003 \\
\hline & All can be bought in one place & -0.006 & 50.023 & 30.090 & -0.085 & 50.009 & -0.012( & 0.015 & -0.010 & 0.016 & -0.025 & -0.038 & 0.057 & -0.012 & $2-0.009-0.063$ & 0.017 \\
\hline & Having favorite goods & -0.015 & 50.059 & $9-0.017$ & $7-0.041$ & 0.003 & 0.019 & -0.011 & 10.009 & 0.014 & -0.015 & 0.006 & 0.026 & 0.002 & -0.0480 .002 & 0.034 \\
\hline & Fresh and good sense & -0.002 & 0.053 & $3-0.043$ & -0.025 & 0.004 & 0.002 & -0.040 & $0-0.010$ & 0.007 & -0.021 & 0.000 & 0.010 & -0.006 & $6-0.0480 .020$ & 0.007 \\
\hline & Cheap & 0.011 & 0.016 & 60.073 & -0.043 & 0.018 & -0.030( & 0.020 & -0.012 & 20.010 & -0.034 & -0.024 & 0.031 & -0.016 & $60.000-0.052$ & -0.008 \\
\hline \multirow[t]{9}{*}{ Shop } & Good atmosphere & -0.014 & 0.020 & $0-0.020$ & -0.057 & -0.005 & -0.007 & -0.013 & $3-0.019$ & 90.008 & -0.015 & 0.009 & 0.025 & 0.000 & $-0.018-0.002$ & 0.022 \\
\hline & Intimacy & 0.026 & 0.078 & 80.003 & 0.001 & 0.023 & 0.023 & -0.017 & $7-0.006$ & 60.000 & -0.014 & -0.009 & -0.002 & -0.014 & $4-0.076-0.012$ & -0.006 \\
\hline & Famous & 0.004 & 0.005 & 50.002 & -0.004 & 0.016 & 0.002 & 0.001 & 0.013 & 0.005 & 0.004 & 0.003 & 0.012 & 0.006 & $-0.016-0.010$ & 0.000 \\
\hline & Individuality & 0.008 & 0.023 & $3-0.028$ & -0.003 & 0.009 & 0.014 & -0.005 & $5-0.002$ & 20.003 & 0.006 & 0.010 & 0.004 & -0.007 & $7-0.0330 .023$ & -0.006 \\
\hline & Good service attitude & 0.001 & 0.021 & $1-0.004$ & -0.018 & 0.003 & 0.014 & -0.009 & $9-0.009$ & 90.009 & 0.006 & $-0.008 c$ & 0.017 & -0.016 & $6-0.0300 .013$ & -0.018 \\
\hline & Product knowledge of clerk & 0.005 & 0.029 & 90.002 & -0.005 & 0.003 & 0.008 & -0.010 & $0-0.023$ & 30.000 & -0.009 & -0.006 & 0.001 & -0.005 & $5-0.021-0.006$ & -0.023 \\
\hline & After-sales service & 0.005 & 0.020 & $0-0.009$ & -0.006 & 50.011 & 0.011 & 0.001 & -0.009 & 90.008 & 0.003 & 0.007 & 0.005 & -0.009 & $9-0.0270 .003$ & -0.012 \\
\hline & Delivery & 0.009 & 0.004 & 40.020 & -0.010 & 0.013 & -0.001 & 0.010 & 0.000 & 0.003 & -0.001 & -0.003 & 0.010 & -0.003 & $3-0.007-0.01$ & -0.005 \\
\hline & Long-opening Hours & 0.010 & 0.005 & 50.055 & -0.032 & 0.007 & -0.017 & -0.006 & $6-0.009$ & 90.006 & -0.012 & -0.018 & 0.029 & -0.021 & $1-0.009-0.071$ & -0.016 \\
\hline \multirow[t]{3}{*}{ Traffic } & Near & 0.050 & 0.138 & 80.103 & -0.022 & 20.035 & 0.024 & 0.013 & -0.004 & $4-0.010$ & -0.05 & & 0.003 & -0.019 & $9-0.108-0.087$ & 0.030 \\
\hline & Parking & -0.023 & 0.034 & 40.023 & -0.074 & +-0.007 & -0.015 & & $4-0.019$ & 90.020 & -0.037 & & 0.043 & -0.012 & $2-0.005-0.065$ & 0.014 \\
\hline & Convenient of bus & -0.001 & 0.021 & 10.003 & -0.005 & 0.014 & 0.000 & -0.011 & $1-0.002$ & 20.005 & -0.010 & 0.004 & 0.005 & 0.010 & $-0.019-0.030$ & -0.005 \\
\hline \multirow[t]{4}{*}{ Pleasure } & Having place for children & -0.009 & 0.000 & $0-0.001$ & -0.031 & 0.016 & $-0.020-$ & -0.001 & 10.014 & 0.008 & -0.003 & -0.001 & 0.020 & 0.022 & -0.0230 .002 & 0.034 \\
\hline & Convenient of public facility & 0.001 & 0.006 & 60.000 & -0.014 & 0.015 & $0.001-$ & -0.007 & $7-0.010$ & 0.008 & 0.005 & -0.003 & 0.003 & 0.004 & $-0.021-0.004$ & 0.003 \\
\hline & Convenient of ATM & -0.012 & 0.028 & $8-0.015$ & -0.036 & 0.006 & $-0.008 c$ & 0.004 & -0.013 & 30.012 & -0.009 & 0.026 & 0.011 & 0.004 & $-0.045-0.022$ & 0.026 \\
\hline & Having place for rest and meal & $1-0.021$ & 0.000 & $0-0.021$ & -0.065 & 50.008 & $-0.017-$ & -0.001 & $1-0.009$ & 90.021 & -0.012 & 0.010 & 0.036 & 0.006 & -0.0010 .016 & 0.028 \\
\hline \multirow[t]{3}{*}{ Adv. } & Attractive advertising & -0.007 & 70.011 & $1-0.009$ & -0.035 & 50.001 & 0.000 & -0.022 & $2-0.016$ & 60.000 & -0.010 & -0.009 & 0.020 & 0.005 & 0.0020 .005 & -0.004 \\
\hline & Attractive event & 0.000 & 0.002 & $2-0.004$ & +-0.011 & 0.004 & -0.013 & -0.013 & $3-0.007$ & 70.003 & -0.004 & -0.003 & 0.010 & 0.002 & $-0.015-0.004$ & -0.011 \\
\hline & Payback & 0.008 & 0.019 & 90.025 & -0.012 & 20.007 & 0.004 & 0.004 & -0.016 & 60.003 & -0.008 & 0.003 & 0.005 & -0.012 & $2-0.013-0.047$ & -0.012 \\
\hline
\end{tabular}

Evaluation on each item, which is goods, shop, traffic, pleasure and advertisement, to Shops in old shopping street by different areas is summarized in Figure 5. It is calculated by using the following formula to balance the different number of question in every item.

Evaluation on each item $=$ Total evaluation of all questions in the item / number of question in the item

As shown in Figure 5, evaluations to Shops in old shopping street by different residential areas are very different and they decreased in the order of Old Town, New Town, Across river and Detached area. 


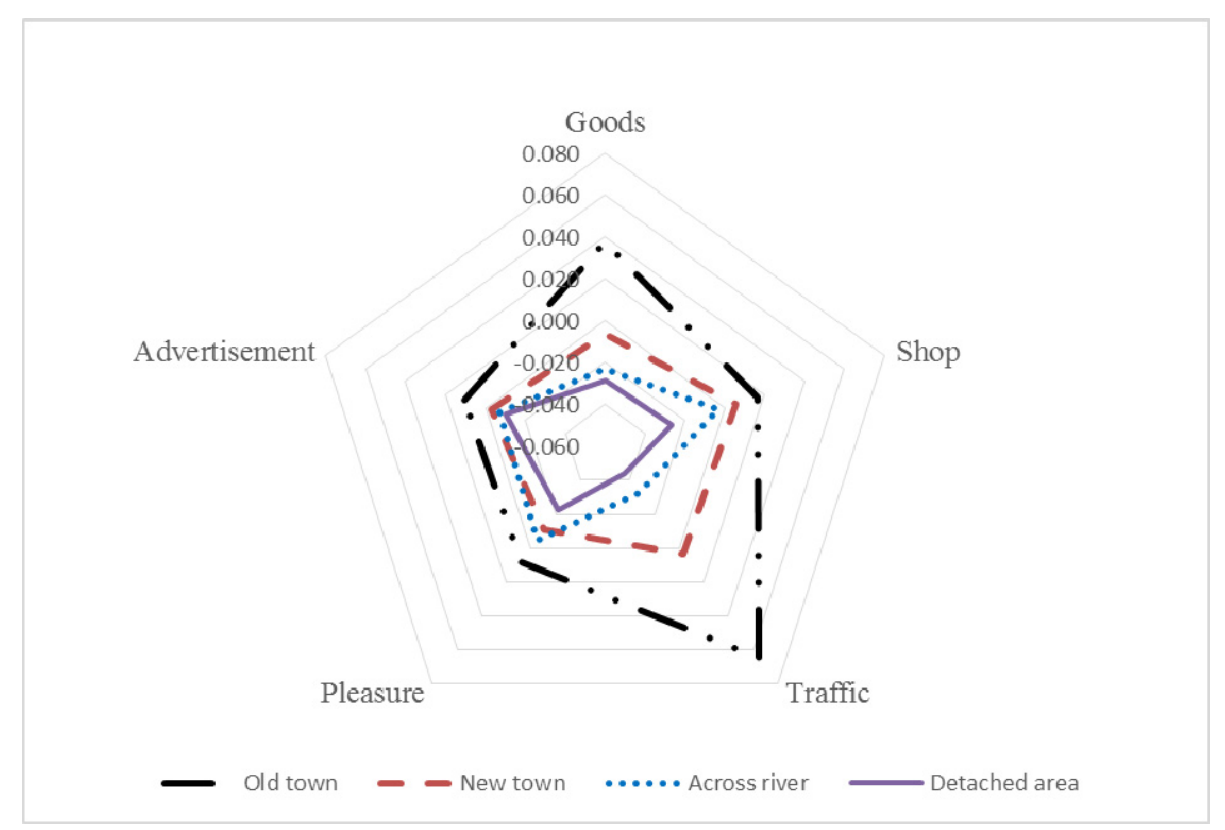

Figure 5. Evaluation to shops in old shopping street by different areas

\section{Discussion}

We summarize background conditions of Kiryu city and the conceivable remedial measures for the old shopping street in Fig. 6. In this figure, we comparethe conditions of Old Town to the conditions of suburbs where many Large-Scale Retail Storesand Large-Scale Malls located.The Old Town where the old shopping street located have less charm to the young because of the causative factors list up in Figure 6.Conceivable remedial measures to improve the listed factors, such as development for EV, public transport usage, using ICT and Word of Mouth in Old Town, etc. are listed at the left side of the Figure 6.

In our study, we investigated not only Action step, the final step in the AIDA steps, but also the previous steps that show the processes to the action. As a result, two hypotheses about the problems of old shopping street mentioned above are considered. Consequently, we suggest below for improving the problemsin the framework shown on the Figure 6. 


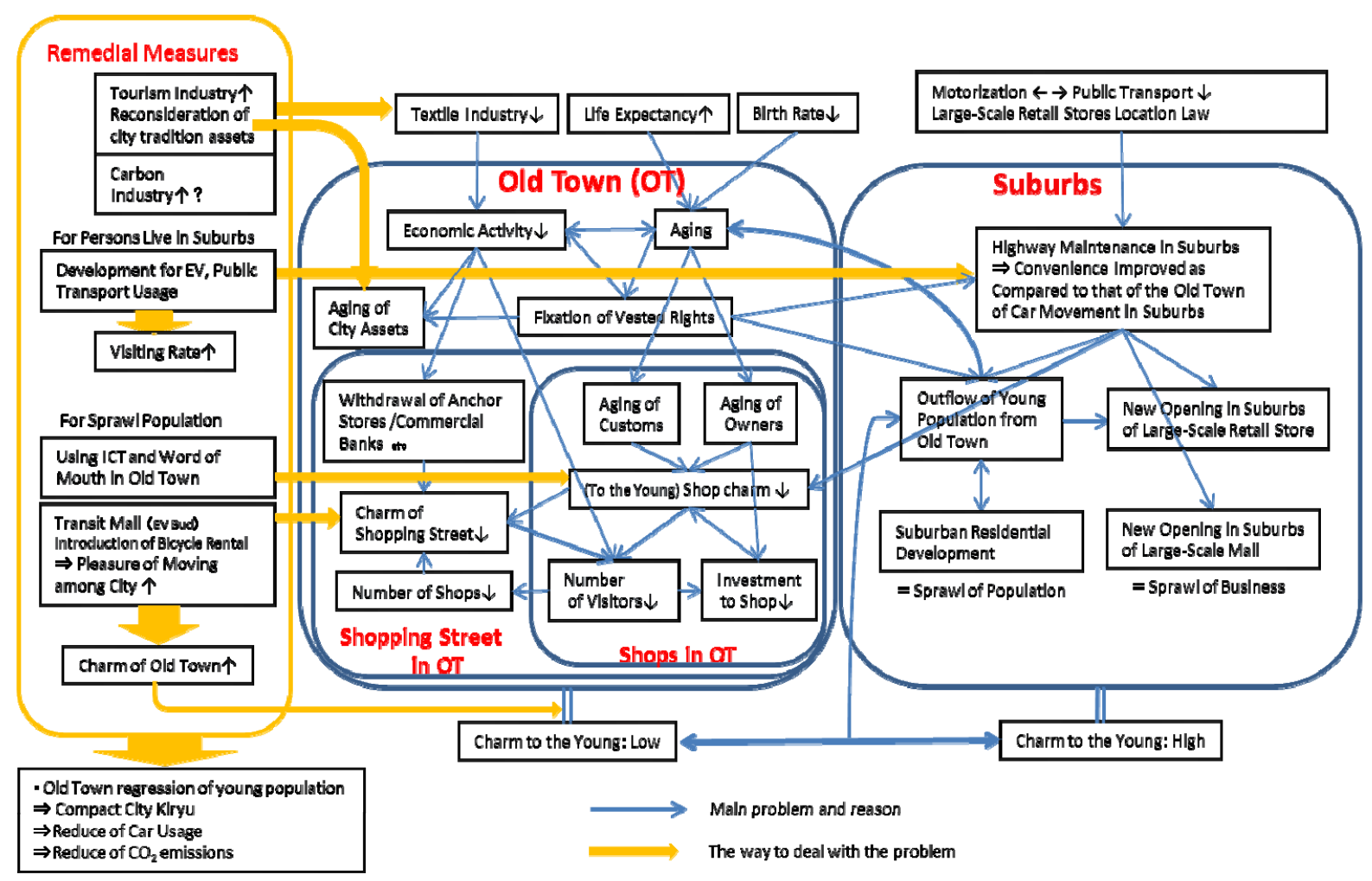

Figure 6. Conceivable remedial measuresfor the old shopping street

First, as indicated by the result in Table 7, shortage of goods verities and cannot buy all in one shop are mentioned as problems by both the customers and the shop owners in old shopping street. Therefore, potential customers think to have to move among the shops in the old shopping street to get all goods they needs. So frequent parking include in and out is necessary since car is used most widely as a means to stores.On the other hand, they assessparking to be verydifficult.Owners mention too parking difficulty and narrow road as problems of old shopping street.It can be thought thatmoving among shops in old shopping street is inconvenience for customers. Therefore, we can get a conclusion that the hypothesis "moving among the shops is necessary in old shopping street and this inconvenience prevents the visiting" is verified.

In order to improve the problem above, direct measuresare to make a block on which existing every individual shopand stores lacking the street are concentrated, and to make parking easier to in and out. However, as mentioned above in the survey of shop owners, the business condition is not so good, so it can be thought that these direct measures are difficult to realize. Therefore, it is necessary to deal with the problems in other view.

Therefore, we propose to create a move means among the shops in old shopping street to deal with the inconvenience to increase the visiting rate. Transit mall is a one of the solution; however, it was difficult because it needed large investment. Accordingly, EV bus (Figure 7) developed by the present project was considered. It is easy to get on and off for its low floor and full of spaciousness for without door and window glass. It can be thought that it can be used easier for the old, children and customers with heavy shopping-goods and can improve the charm of Old Town. Now, examination service of the EV bus began, and the service is being evaluated. 


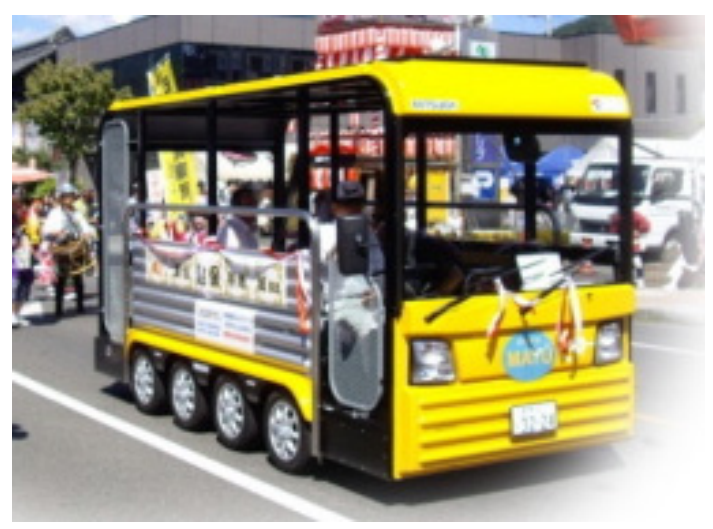

Figure 7. EV bus

Second, as indicated in Section 3.2.3, evaluation on old shopping street is very different by the four areas and decreased in the order of Old town, New town, Across river and Detached area. For some items, such as traffic, evaluated different by residents in different living area is reasonable. As toother items, such as goods, shop and pleasure, it is not reasonable. We found that the usage of old shopping street also decreased in the order of Old town, New town, Across river and Detached area. That is to say, the more usage of old shopping street, the higher evaluation it receives. Then, we can say that the charm of old shopping street is not known by those who seldom using it. Therefore, we can get a conclusion that the hypothesis "the charm of the old shopping street is not be known well" is verified.

In order to improve the problem above, it is necessary to find a good way to make the charm of old shopping street to be known by those seldom using.In ourother study, Gaowa (2013) clarified that Word of Mouth (henceforth WOM) is an effective way to disseminate information and confirmed that new information is disseminated in the network if some constituent members of the network acquire it. Moreover, thinking about the aging population composition of Kiryu City, we believe that face-to-face WOM, the traditional way of disseminating information, will be more effective than Internet or something like SNSin this case. In addition, since there are some events, such as antique market, is hold on regular in Kiryu city, effective using of event can be thought as a good way to attract new visitors and make them know the charm of old shopping street. Then the charm of old shopping street, in other word, information will be disseminated in the WOM network of the new visitor and the visiting rate to Old town will be grown.

As described above, two hypotheses above are verified by statistically analyzing the data obtained by the surveys. We hope we can contribute to build the bustling street in compact city Kiryu by showing a clear direction for improvement of the old shopping street.We think that these remedial measures increase the charm of Old Town and the citizens' visiting rate to Old Town.

\section{Acknowledgments}

The research described here was conducted as part of a project named "Construction of the Town of Kiryu for the Future with Anti-Global-Warming through Regional Power" supported by the Japan Science and Technology Agency (JST).

We would like to thank Kiryu city hall, Kiryu Chamber of Commerce and Industry, all of the citizens of Kiryu city and the owners of shopping street for their cooperation in the survey.

\section{References}

Dholaki, R. R. (1999). Going shopping: key determinants of shopping behaviors and motivations. International Journal of Retail \& Distribution Management, 27(4), 154-165.

Finn, A., \& Louviere, J. J. (1996). Shopping center image, consideration, and choice: Anchor store contribution. Journal of Business Research, 35(3), 241-251.

Gorter, C., Nijkamp, P., \& Klamer, P. (2003). The Attraction Force of Out-of-town Shopping Malls: A Case Study on Run-fun Shopping in the Netherlands. Tijdschrift voor Economische en Sociale Geografie, 94(2), 219-229.

Lewis, E. (1985). Financial Advertising. Taylor \& Francis. 
Seki, Y., Luis, C. Manrique, K. A., \& Takarada, T. (2012). Evaluation of Micro EV's Spreading to Local Community by Multinomial Logit Model. Industrial Engineering \& Management Systems, 11(2), 147-153. http://dx.doi.org/10.7232/iems.2012.11.2.147

Spector, P. (2008). Data manipulation with R. Springer, 2008.

Thomas, C. J., \& Bromley, R. D. F. (2003). Retail revitalization and small town centres: the contribution of shopping linkages. Applied Geography, 23(1), 47-71.

Wa, G., Seki, Y., \& Takarada, T. (2013). Relationship between Word-of-Mouth Network and Behavioral Tendency-Preliminary Research for Local Downtown Activation. International Journal of Marketing Studies, 5(5), 1-11. http://dx.doi.org/10.5539/ijms.v5n5p1

\section{Copyrights}

Copyright for this article is retained by the author(s), with first publication rights granted to the journal.

This is an open-access article distributed under the terms and conditions of the Creative Commons Attribution license (http://creativecommons.org/licenses/by/3.0/). 